\title{
Life intellectual and urban sociability: Bethlehem of in rubber belle epoque (1880-1910)
}

\begin{abstract}
The last quarter of the nineteenth century and the first decades of the twentieth century were essential to the contemporary history of the Amazon; the region became integrated into the mechanisms of industrial and finance capitalism and became the key component of international economics and culture through the chain of latex production. The dynamics of the reproduction of capital formed the axis for the globalization of culture, in the forms and in the representations of the so-called belle époque, forms the widely proclaimed civilized and Appropriate for the social subjects of progress. Theater, literature and musical associations constituted the marks of urban sociability, reproducing on a scale place in the Belém of que era, the settings typical of the belle époque. Even considering certain particularities, these sites can be the Regarded the mimetic configuration of a globalized capitalist bourgeois culture of the fin de siècle.
\end{abstract}

Volume 3 Issue 2 - 2018

\author{
Gerald Martyrs Coelho \\ Associate Professor, Federal University of Pará, Brazil
}

Correspondence: Gerald Martyrs Coelho,Associate Professor, Federal University of Pará, Brazil,

Email gmartirescoelho@gmail.com

Received: August 04, 2017 | Published: March 19, 2018

\section{Introduction}

What in the lexicon of Cultural History was set to belle époque it indicates a complex process of cultural, social and mental relationships developed within a recognized corpus historically as the bourgeois culture and its claim within the hegemonic frames of industrial capitalism in the late of the 19th century. On behalf of the identity of a time whose social subjects emerged from the new dominant economic and social conditions in the world's capital, the belle époque implies recognizing languages, tastes, attitudes, aesthetics, sociability that produced in the hegemonic centers of industrial capitalism economy, reproduced On a planetary scale, also in the condition of the ways of being and of acting in times that implied the triumph of Progress and the affirmation of Civilization. The mythology of the belle époque was expressive and rooted enough to build their representations and globalizes them. In this sense, Paris emerges at the end of the nineteenth century as a great and powerful metaphor, space-synthesis of an exquisite, elegant, cultured and civilized way of life. The mechanisms and behaviors of bourgeois sociability produced thereby images of a golden age of social life, whose ways and organic circulation veins were the boulevards of Paris. The bhe époque, ultimately edulcorou the dramatic dialectic of revelation and concealment, appearance and essence, in the limit as everything was solid evaporates in the air.

Values, codes and rituals of the culture of the belle époque in theater condition of civilization, have spread to a greater or less extent by contemporary societies. Paris, Lisbon, Buenos Aires, St. Petersburg, Vienna, Belem and Manaus, cities of distinct social and physical topographies, were integrated into the world circuit of bourgeois culture, insofar as they were linked to the world market chain. Bourgeois culture bépoque he transitioned the same circulation channels of goods, capital and production of goods, which meant clearly defining the meaning of the globalization of the capitalist economy and the symbolic capital of bourgeois culture. The belle époque, understood as a manifestation of the Golden Age of the urban culture of contemporary bourgeoisie, whose traditional paintings, as seen, refer to the Paris of the late nineteenth and early twentieth century's, it has always been a domain visited by the Brazilian social narrative. Even the urban transformations of cities such as Belem and Rio de Janeiro in the same period, were treated as specular dimensions of the belle époque matrix in social and mental latitudes of the Brazilian tropics. The reading of the chronicle of an Olavo Bilac and a João do Rio, for the Federal Capital and that of a Humberto de Campos and an Eustáquio de Azevedo, to Belém do Pará, reveals, this reading, that its authors believed that the Essential scenes of the culture and urban and bourgeois sociability of Paris had been transposed into the Brazilian cities in question. The Rio de Janeiro, Belem or Manaus, but Brazil as a whole, civilise-parodying journalist Figueiredo Pimentel, one of the heralds of the belle époque and culture of the boulevards of Rio de Janeiro, whose column "The Binoculars" published by News Gazeta newspaper, had become at the helm of bourgeois ship in the Federal Capital in the early twentieth century. This supposedly historical aphorism crossed decades of Brazilian social thought, just as it fueled the country's social imagination about a progress and a civilization that established itself in the country as universal.

The natural inclination of our men of letters and of our artists would have succeeded in producing the social and mental ambience of cities such as Paris, Vienna, Lisbon, St Petersburg and the conquests of progress and civilization on such diverse cultural soil. Since the final years of the Empire, the Europeanization and laundering of Brazil, homologies of progress and civilization, assumed, by virtue of a discursive identity, the visible and detached face of the Brazilian Nation. Therefore understandable that for the mentality of urban elites of Brazil, the belle époque crowned the historical commitment to build the real country whose founding structures was in the imaginary country. From Nature we went to Culture, we got to History. More recently, in the fields of Social History, Cultural History and Literature, the belle époque Brazil, its symbolic languages and their social representations has been the subject of a new reading. 
Both in terms of Rio de Janeiro as Belém and Manaus, reference scenarios civilizar- if Brazil in the late nineteenth century to the twentieth, the belle époque pa ssa to other fields of social thought. This passage, of course, takes place in several domains, inasmuch as the visited universe contains fields formally differentiated from its organic, although, in one way or another, they concern the forms and representations with which capitalism and Bourgeois culture globalized. In the case of Amazon, revisit the belle époque of the major regional capitals implies, ultimately delve into areas of regional history for a long time covered up by the very facies of its founder speech. Only by way of another speech, the questioning of narrative genealogy belle époque Amazon, you can keep open the recent past of society and Amazonian culture. ${ }^{1-10}$

\section{Mirrors and images of civilization}

In one of the known passages of the Communist Manifest 1848, Marx and Engels, concerning the power of subversion of capitalist economy and to enhance the dissolution of the materials and mental bases of the European Society, said, on the way of forward production of industrial capitalism and the new social relations of production, everything was solid cutting up in the air. The solid definition of the era of industrial capital, of financial capital, meant, too, Eric Hobsbawm would say, the construction of a correlative era, the empire era. In the historical lexicon, empire implies a sense of globalization, taking the classic examples of the Macedonian empire and the Roman Empire, globalization of material power and cultural power of Macedonia and Rome in the ancient world. Still in the Modern Age, the Iberian overseas expansion produced another globalization of the material power of mercantilism and the cultural power of the Luso-Hispanic societies of Europe, a process of hegemony, mediation and synthesis developed in the long term between the cultures involved in its historicity.

In the case of the globalization of processes inherent in the industrial capitalist mode of production - sources of raw materials, markets, labor and financial capital support - their development took place on social realities and historical figurations already incorporated into the dynamics of the modern European economy since the era of Mercantilism. Because of this aggregation of material and cultural conditions have historically consolidated in the specific case of the belle époque, expansion, globalization of bourgeois culture from the hegemonic centers of the capital was more dynamic and comprehensive. Through the channels of circulation of capital, too, the discourse of Progress and Civilization circulated in the form of the many representations assumed by this same discourse.

The arts, literature, lyrical scene, dress and gesture, the exaltation of good taste, the ideal of the planned, clean and hygienic city, the cover-up of poverty and beggary, worldly sociability, aesthetic and literary aspirations Present in the associations and lyrical-musical associations. This form and this model of a new living become the ideology of the culture of the civil man of the end of the nineteenth century. Buried the revolutions and overcome the discontinuities produced by the revolutionary processes in contemporary Europe, it returned to the historicity of historical, diachronic, historicist, finalist and utopian time. This entire big picture is, in short, the kaleidoscope of signs and rites that fed the myth of the belle époque as a representation of the Golden Age of Progress and Civilization, a historical subject construction of state to be held universally thanks to the achievements of Science, machinery and globalized civilization processes. There was a belle époque in the Amazon? The answer to this question implies a bundle of conceptual and empirical problems faced by Brazilian historians in general and in particular Amazonians. After all, the same question applied would in Rio de Janeiro in the early twentieth century, when it was mentioned earlier, the city, the Federal Capital, in the eyes of its bourgeoisie, the government and its men of letters, finally, civilize themselves. The question, in itself, is one of those arguments whose answers sought few times advance in order to illuminate a given cut of the recent history of the Amazon. If, for the sake of accepting a lexicon applied to the reading of the cultural, social and material realities through which the rubbery Amazon passed and forcing a correlation with the scenarios of Europe of industrial capitalism, bourgeois culture and sociability of the end the late nineteenth and early twentieth century, it is believed, by transposition and terminological adaptation, then the Amazon lived his, repeat, its belle époque.

If, however, a belle époque is considered only historical pictures of Belém fin de siècle, with the forms of their urban sociability and the rhythms of his consumerism, we lose sight of the complex transformations that Amazon began to suffer the first half of the 19th century. Consumer goods and cultural goods of Paris were already present in the daily life of Belém; the steam navigation of the Amazon, initiated around Mauá and its Company of Navigation and Commerce of the Amazonas (1852), internalized this new stage of the economic and social daily life in Pará. Foreign travelers and chroniclers here by then admired with the presence in Belém and Santarém, goods, values and customs of the French Empire II culture. The perception of the ends of this bow is that it allows, ultimately, that the observer does not fall into the many traps installed by historical and sociological reductionism, especially regarding the idea that the belle époque Amazon manifested as only an immediate, short - sighted mimicry. It would be as if, from one moment to another, segments of the society of Belém, Santarém and Manaus discovered in the shops of their cities a set of different products, strange and that they used them because they came from a mysterious place, unknown and exotic place called Paris. And that the cafes and theaters looked like phantasmagoria arising from the enchantment of the forest.

As rubber increased in importance and in international market prices, the Amazon became more integrated, through the lives of dependency relations, into the hegemonic centers of industrial and financial capitalism. And the ways of circulation of capital would be the same as the circulation of the symbolic capital, that is to say, of the bourgeois culture in the accelerated and broad process of globalization. It is worth repeating previous observation, in which Marx and Engels wrote in 1848, the purpose of capitalist subversion of power: that everything was solid cutting up in the air. In this sense, as early as 1850 , Bethlehem accused, in the panorama of culture and urban sociability that the foundations of the ancient forms of Lusitanian culture were beginning to disintegrate. As pointed out earlier, segments of the local society dressed, amused themselves and behaved in the French.

From this point of view, therefore, there is no denying that Bethlehem and the Amazon as a whole met its belle époque, understood, it is clear, as a manifestation and representation standards of bourgeois culture that mendializava, a new stage, along $t$ It is instructive to recall the words of Prince Albert at the opening of the 
London International Exposition in 1851, whose greatest emblem was the Crystal Palace: the achievements of Civilization and the achievements of Progress will be carried to the four corners of the world. This is the case to ask, would be the belle époque something different than vaticinara in the British capital the husband of Queen Victoria? What is essential in this process is not the migration/ transposition of the values, representations, languages and rituals of the culture of the European bourgeoisie. Rather one must realize the extent to which local society, it's learned and literate segments, felt as participants in the process of building the material and mental scenarios that harbored the forms of Civilization and Progress arrived here. Otherwise, the belle époque was only a metaphor, a complex process of mimesis, which did not really happen.

The sense of belonging to a entificado time and mythical, turning the singular subject in world citizen, a man of modernity, tuned and framed our intellectuals, our men of letters within the larger panel of European culture fin de siècle. An Olavo Bilac, a Joao do Rio, a Figueiredo Pimentel, in Rio de Janeiro, an Augusto Montenegro, a Just Chermont, an Eustáquio de Azevedo, in Belém do Pará, felt like subjects of a culture - and as cultural constructors - Matricially out of place, but legitimized by the social gens of its original organic. It was therefore necessary to create conditions so that the compounds of European civilizational processes could flourish in other cultural latitudes.

For example, the legitimizing political argument of a lyric theater in Pará and Rio de Janeiro, even with decades of difference in manifestation favorable to one and the other, was the same: music and lyrical scene went hand in hand with civilization to argue the logic of the discourse of the intellectuals of the belle époque Pará and know the structure and functionality of institutional practices they have developed or which were participants also mean knowing the identity and worldview of the subject of civilization And Progress created by the globalization of culture and tribune of the great and planetary discourse of bourgeois modernity. To gaze upon the belle époque in Bethlehem is to resume old paths of historical memory, collective memory and the very discourse of history. Substantial differences indicate the ways and places these narratives, although, as will be later argued, the same came, the same wire seems to lead the body of many speeches built on Bethlehem who lived the boom of Amazonian rubber and met representatives of urban culture and sociability triggered by globalization of standards and cultural rites of the European bourgeoisie fin de siècle. The impact of the changes processed in the urban daily life of Bethlehem that passed from century XIX to the XX was powerful enough to generate the necessity to narrate it. And this narrative, it should be noted, it was also given in the form of the image, the photographs and postcards seeking to capture and freeze the radiant visions of s Golden Age of Civilization and Progress.

There is no doubt about the importance of newspapers to the mundane memory of belle époque in Bethlehem, especially the paths of chronic and records factualizavam urban sociability. In the pages of the journals The Pará Province and North Leaf, both already circulating in the capital of Pará in the late nineteenth century and at the time technically exemplary newspapers among the few existing in the Brazilian press, you can catch speech fractions of civilization subject Belle époque rubber. Shops, cafes, theaters, fashion, gatherings, conferences, exhibitions and more, of course, the exaltation of urbanized and sanitized the acidic appears on the big picture condition, powerful everyday panorama of a capital played by the various representations of a new time. The periodical press of Bethlehem at the time and most newspapers of associations and professional association's inventariavam, so to speak the places, the forms and subjects that lent a given visibility to the belle époque of Bethlehem.

The debacle of the rubber economy in the years 1910 to the present day, the Bethlehem of belle époque met sporadic visitations of historical research, most often in the fields of economic history and not in the fields of cultural history. In such cases, the eye of the historian was more clearly focused on latex production chain and the mechanisms of financing, marketing and movement of the product. The model city of tropical civilization was, in essence, the commercial plaza, its banks, its import and export houses, its credit establishments, its varied commerce and its ability to feed the tentacles that brought trade to the rubber tree and brought the urban emporium of the capital. In any case, the economic readings of Belém and the Amazon of rubber marked a significant narrative advance compared to the merely mnemonic and nostalgic chronicles that sometimes punctuated one or another publication of the genre. ${ }^{11-20}$

\section{History and stories of spaces belle epoque}

Between the late 1990s and the early 2000s, not only the incursions of the Amazonian economic history provided, as a component of its scientific object, reads and looks at society and culture that developed at the Extractives and the chain of its commercialization. New approaches have been constructed so as to escape from the economic models of analysis and thus to privilege the domains of culture, sociability and daily life of social groups. Likewise, these readings favored especially a large area of Bethlehem of Belle Époque, a domain high visibility and high meaning as speech. It is, namely, the urbanized city, sanitized, equipped with large urban facilities, that is, the city metaphorically considered gestated body for Civilization and the Progress and whose set of representations is in Belém do Intendant Antônio Lemos (1897-1911) and Manaus Eduardo Ribeiro Governor (1892-1906), cities, further up, which state intervention was also disciplinarian and segregated to maintain their respective centers as civilizational mirrors and civilizing.

\section{History and stories of letters belle epoque}

The large, recent historical and historiographical investment in belle époque Amazon, despite the new problems and new approaches proposed focused its approach, as before it was pointed out, especially in scenarios and urban landscapes of cities that Civilization and Progresso made it appear in the middle of the Brazilian rainforest. Regardless of epistemological guideline that confers these readings the condition of new theoretical, empirical and methodological artifacts, their movements, repeat and revolve around the same orbit and the physical space compounds of capital Belle Époque Amazon. Such contingency is dictated by the very nature of the theoretical and methodological strategy constructed by its authors. Thus it requires the dialogue that it maintains with a past, recreating pictures and readings, which in no way disavows or compromises the object as epistemological identity. There is indeed a narrative record of the belle époque of Bethlehem seeking praise and crystallize the epicenter of the lettered and worldly culture of the then capital of Para. Men who lived intellectual and social realities of latex Belem left significant 
records of a time which were subject and object. Names like Humberto de Campos, Theodoro Rodrigues, Eustáquio de Azevedo, Paulino de Brito and João Lúcio de Azevedo - to name just a small number of men of letters of Belém fin de siècle - produced a chronicle, a memory, a text entry mode To exalt the social time that they lived, they, they repeat, subjects of the Civilization and the Progress. How, however, these universal attend and play their assumptions in the discourse of lettres de gens belle époque of the Bethlehem of rubber? Answering this argumentation means to gaze beyond the boulevards, gardens, public services, urban development, precisely the outer and most recognized face of Bethlehem who lived to remind expression of the time, the Folies du latex.

\section{Scenes of a life not necessarily bohemia}

It seems clear that many can be the paths toward the mentality of Bethlehem of belle époque. Some of these routes were already mentioned in previous sections and relate to many pictures at various exteriors of state capital in the golden years of the latex economy. It was noted, however, that many men rubber Bethlehem of letters lived the intellectual condition of the temp of Progress and Civilization. His speeches were clearer in the equipment of modern life, communications, electricity, hygiene and urban sanitation and steam navigation. Therefore, these men of letters, au delà de la vie de bohème, founded and maintained cultural associations and produced a type of narrative intended to be reflective of the intellectual headquarters of Europe, read up, the Paris whose spectra rubber seemed to be displaced as tropical fantasmagorias.

To explain better, the city of Bethlehem, which was in the late nineteenth century, knew and lived with a mosaic of cultural associations, literary-musical societies, literary societies, musical societies, cultural associations of trade professionals, plus a good number of newspapers and magazines Born as vehicles of this action of the local writers, some of which within these associations. Most of these small unions of men of letters and their publications had quick and fleeting life, but by no means cease to be important as mirrors to reflect the relationship between exterior and interior of the Bethlehem of belle époque, between the modern city and Micro-organism network of its urban and intellectual sociability. Among the many intellectual associations active in Bethlehem who won the nineteenth century and reached the early years of the twentieth century, were the following: Literary Workshop Club Coelho Neto, Apostolate Cruz e Souza, Gremio Estudantino Pará, Gremio Literary Fagundes Varela, School Literary Antônio Lemos, das Letras Workshop, Upper Room of the New and So ciety of Men of Letters of Para.

The literary magazines, also ephemeral, did not, for this very reason, leave projecting the very shattering of modernity. They were, therefore, vehicles, mirrors, same, of the exhibition of the images of a time of speed, speed and shattering. The Athenaeum, The Dawn, The Lábaro, Bohemia Literary, Para Modern, The Literary Voice, The Academic Journal, not to stretch over the list, were part-among other titles this frenzied participation of provincial writers in the invention / development of an organism Intellectual proclaimer of an Amazonian inscribed within the framework of the globalization of the economy and culture, space of Civilization and Progress. Some of the intellectual associations in Bethlehem of belle époque had more or less long life, while others, especially those who have maintained social and institutional relations with the state and have earned the official legitimacy and counted on the official patronage, won the afirmaram- With his academic legends, on historical time. These associations, albeit in a private domain, would count in their membership to some of the state apparatus key names and so turned themselves by class habitus process in agencies at the same organic and reflective time of culture and Cultural politics in Bethlehem that closed the nineteenth century.

Distinguished, so the other intellectual associations of the period, the social flagship carrying, would appear and would be said in the world of letters and urban sociability of Belém the end of the Mina Literary nineteenth century, Para Academy of Letters and the Historical and Geographical Institute of Para, the last two declared of public utility by the State Government, a situation that gave them a tint of official cultural associations and so proclaimed and recognized by the government. In 1889 the effusive and even civic celebrations of the first centenary of the French Revolution were given, when the hearts and minds of the educated elites of Belém of rubber and of the educated urban elites of Brazil as a whole turned to Paris, the capital of Grao-Pará was a shop window. Open the doors of the Peace Theater in 1878 and then started the first season lyrical in opera house built in the middle of the rain forest, civilization will carve your large mirror, claiming the symbolic power of a culture that mundializara their languages and their Representations. The opera, that was an example the production of Carlos Gomes, held almost simultaneously lyrical scene of Milan, Lisbon, St. Petersburg, Rio de Janeiro and Belém do Pará. If, at the end the 1850 s, shops selling French lace And bookstores made Lamartine's literature known, the 1880s was decisive for the construction of a network of spaces that built and moved the behaviors of Belém's urban sociability of rubber. Even the formation of the intellectual patrimony of its educated elites!

Banks, commercial houses, magazine theaters, cafes, musical associations, newspapers, groups of writers, commercial schools made up the visible, urbanized and proclaimed Europeanized face of a city that the pace of the latex economy was speeding up. In this sense, the processes of reproduction of the elements of the globalized chain of culture that the hegemonic society of industrial capitalism produced at the end of the nineteenth century multiplied. It was, we must emphasize again, what the discourse of the progress of bourgeois optimism pointed to as the inevitable and necessary globalization of civilization and the advantages it would bring to the peoples of the world. So, repeat, said Prince Albert in London, the International Exhibition of 1851, whose icon par excellence was the famous Crystal Palace. Undoubtedly, the consumption of French letters, whether in the form of literature, sociology or philosophy - including scientific philosophy - or that of English scientific philosophies, especially of Evolutionism, marked the formation of the educated elites of Belém of rubber. This is an area of ellb and epoque harder Amazon to work, in that it involves the treatment of a cultural specificity which, in most cases, have fragmented public records. In any case, as noted earlier, references to the arrival in Belém of titles from a variety of French literature can be followed in the newspaper register from 1850, which certainly explains the fact that some of the leading newspapers in Bethlehem at the end of XIX century to maintain spaces destined to literary and scientific subjects. In the case of the most visible French letters, of Lamartine Comte, through Hugo and Saint-Simon, the educated circles of Belém fin de siècle showed up strongly provisioned by the academic culture of the nineteenth century France. 
Only in relation to the presence and strength of Comte Positivism in Belém, it is important to note that José Veríssimo, who lived in the capital of Pará between 1880 and 1884, acted as a positivist doctrine. In the newspaper pages as Gram-Para Journal and Gazette News, Verissimo worked systematically Comtean thought and matters that stamped on the second of these journals served as the foundation for the work entitled Emilio Littré, given to the press by José Veríssimo in 1881. Two years later and in addition to its line of theoretical reflection, he would publish their Amazon Magazine, out in eleven numbers and transformed into intellectual exercise space of our men of letters. Between 1896 and 1897, he served in Belem cultural association Order and Progress, bringing together engineers, public figures and men of letters. His newspaper, also called Order and Progress, was doctrinal and political philosophy page space, stamping on his head the maximum doctrinal Comte: Love in principle, the order is based and progress finally.

The statement of positivism among the tables of the educated elites of Belém the late nineteenth century is doubly reflexive. The political perspective filters the presence of positivist doctrine among the Brazilian Republicans, many of whom made the Republican campaign inspired by the teachings of Benjamin Constant in Rio de Janeiro, like Lauro Sodré. At philosophical prism comes to the progress of speech in the form in which it was reset at the end of the nineteenth century Brazil and from which it Lauro Sodré Para governor (1891-1897) was a great representation herald. In general, therefore, it was very expressive brand of positivism in driving the thinking and practices of intellectuals Bethlehem of Belle Époque rubber. Some indicators may shed light on the intellectual life - including, of course, its scientific dimension - the Bethlehem who went through the second half of the nineteenth century. To the extent that culture is one of the levels, the symbolic, the concrete relations of societies with each other, it is evident the linkage of time man of letters to the headquarters of European thought and the readings produced about the meaning of Progress and Civilization. After all, there was in the previous passage, the Belle Époque embodied and represented the bourgeois optimism in the inevitability of progress and civilizing the time of the technical achievements and material achievements of capitalism extolled. The organization of Philomathic Society Pará (1866) the establishment of the Literary Mine (1895), through the establishment of the Ethnographic Museum and Natural History (1871) - after Museu Paraense Emílio Goeldi - science and literature were thought of as attributes and virtues of the social subject a time in which Progress and Civilization were categorical imperatives of history.

The dynamics that led to the constitution, to January 1, 1895, the cultural association Mina Literary reveal that the constitution of a body of men of letters was strategic to the definition of a socially representative intellectual field, recognized and legitimized in the cosmopolitan and worldly Belém the end of the nineteenth century. One of the main figures of this movement, J. Eustáquio de Azevedo and defines the figure of the intellectual, but especially the polygraph, the writer of many narratives that dominated the learned scenarios of urban Brazil of the late nineteenth century, in particular the Rio January in the years of the Belle Époque Rio. Articles, essays, lectures, poetry, novels and more translations from English and French writers, left the penalty Jacques Rolla, long pseudonym used by Eustáquio de Azevedo. The appearance of Literary Mine was recorded and praised that same opportunity in the pages of The Paiz, of Rio de Janeiro, precisely reveal the men of letters of effort, observed by the telescope assestado the Federal Capital, played the intellectual life of the peripheral Brazil, provincial, kind of crossed the literature and know the unimaginable limits of the country. The Literary Mina kept an organization marked by a certain form of esotericism, relating to deep ground and its members to the quality, the value of noble minerals, rare and precious gems. The Literary Mina was shown symbolically close to the ideal of a Masonic philanthropy and carbonaria. His paintings gathered almost all the men of letters of Bethlehem, recognized for its intellectual role and its social identity. Miners were also Lauro Sodré, Serzedelo Correia, Paes de Carvalho, Américo Santa Rosa, Tito Franco de Almeida and still Guajará and Marajó Baron of Baron. ${ }^{21-29}$

Much more than a company dilettanti, the Literary Mine sought to maintain a basic editorial activity, significantly significant considering the editorial difficulties in a market outside the bookseller axis of Rio de Janeiro and São Paulo. After all, the book was a product, a market commodity, governed his existence by the laws of buying and selling. Of the titles given to the press under the seal of Literary Mina, some indicate the presence, consumption and textual redefinition of Zola's naturalism among the intellectuals of Bethlehem, as did, in fact, the very Eustáquio de Azevedo. Other published titles reveal the eclectic taste of the time, marked by chronic, by text, by the poetry of circumstance, shapes, ultimately aesthetic phantasmagoria that the Belle Époque produced for divertissement in the halls of worldly culture of the time.

And at the turn of the nineteenth to the twentieth century, during the consulate of Intendant Antônio Lemos (1897-1911), state investment in the urban modernization of Bethlehem, with its wide avenues, gardens, squares and monuments and more and sanitation services hygiene lent a cosmopolitan character to the city. The Pará capital caused astonishment to men like Euclides da Cunha, who passed through here in the dawn of the twentieth century. The Belle Époque of Bethlehem of rubber had fastened their images, expanded its myths, its legends taken root. As the Paris of Baudelaire, here too miserable cut the avenues. Soon the Progress and Civilization would rescue the fields for the Golden Age.

\section{Acknowledgements}

None.

\section{Conflict of interest}

Author declares that there is no conflict of interest.

\section{References}

1. Eustachian AJ. Para literature: historical overview of their movement. Belém: Week s/d.

2. Henry BW. The Naturalist on the River Amazons. Belo Horizonte: Itatiaia, São Paulo: Edusp; 1863.

3. Walter B. Modernity and modern. Rio de Janeiro: Brazilian Time; 1975.

4. Ernani K. In the modern threshold: Studies on Friedrich Nietzsche and Walter Benjamin. Belém: Paka-Tatu; 2003.

5. Theodoro B. Notions of chorography of Pará. Belém: Company Graphic Amazon; 1919.

6. Humberto C. Oak trees and rose bushes. 2nd ed. São Paulo: José Olympio, 1934.

7. Mártires RG. The brightness of the supernova: the beautiful death of Carlos Gomes. Rio de Janeiro: Acting, Belém: UFP; 1995.

8. Mártires RG. In the heart of the people: the monument to the Republic in Bethlehem (1891-1897). Belém: Paka-Tatu; 2003. 
9. Henri C. Les français en Amazonie. Paris: Picard-Bernheim et Cie; 1887.

10. Euclid C. A paradise lost. Amazon assays, Brasilia: Federal Senate; 2000.

11. Maria DA. The belle époque Amazon. Rio de Janeiro: Jorge Zahar; 2000.

12. Mascarenhas DE. The illusion of Faust: Manaus - 1890-1920. Manaus: Valer. 1999, 189 p.

13. Otto F. Olimpia: Paris at the time of the Impressionists. São Paulo: Companies das Letras; 1993.

14. Melchior HL. Le petit monde des cafes et Debits parisiens. Paris: PUF; 1990.

15. Jeffrey ND. Belle époque tropical: society and elite culture in Rio de Janeiro at the turn of the century. São Paulo: Companhia das Letras; 1993.

16. Dolf O. Tables Paris: anti-bourgeois aesthetics 1830-1848. São Paulo: Companhia das Letras; 1997.

17. Renato O. Culture and modernity. São Paulo: Brasiliense; 2001.

18. Renato O. Globalization and culture. 2nd edn. São Paulo: Brasiliense; 1994.

19. Nicole R, Michel T. Sociabilites intellectuelles; lieux, milieux, réseau. Paris: Center National de la Recherche Scientifique(20); 1992.
20. Moraes RC. Mina Literary Northerner of Azevedo Eustáqio en' "The Literary Pará de Theodoro Rodrigues”. Belém: Publisher of UFP; 1997.

21. Campos RD. Belém hot of yore. Belém: Secult; 2005.

22. Carlos R. Antônio Lemos and his time; political history of Para. 2nd edn. Belém: Cejup; 1996.

23. Roberto S. Economic history of the Amazon (1800-1920). São Paulo: TA Queiroz; 1980.

24. Jerrold S. Paris bohemian; culture, politics and the limits of bourgeois life. 1830-1930. Porto Alegre: L \& PM; 1992.

25. Leandro T. Santa Maria de Belem do Para Grand. Rio de Janeiro: Civilization; 1963.

26. Vicente S. The music and the time in the Grand-Para. Belém: State Council of Culture, 1980.

27. Nicholas S. Literature mission: member's tensions and cultural creation in the First Republic. São Paulo: Brasiliense; 1983.

28. Eugen W. France fin-de-siècle. São Paulo: Companhia das Letras; 1988.

29. Barbara W. The rubber in the Amazon and decay expansion (18501920). Sao Paulo: Hucitec-Edausp; 1993. 